\title{
Analisis Motivasi Mahasiswa dalam Menempuh Kuliah pada Program Studi Manajemen Jenjang Strata-1 Sekolah Tinggi Ilmu Ekonomi Jambi
}

\author{
Prayetno Agustinus Sitanggang*1, Friska Artaria Sitanggang ${ }^{2}$ \\ Sekolah Tinggi Ilmu Ekonomi Jambi ${ }^{1,2}$ \\ *correspondence email: prayetnoagustinus@yahoo.co.id
}

\begin{abstract}
Abstrak. Tujuan utama dari penelitian ini adalah menganalisis motivasi mahasiswa Program Studi Manajemen dalam menempuh pendidikan pada Sekolah Tinggi Ilmu Ekonomi (STIE) Jambi semester ganjil Tahun Akademik 2020/ 2021. Metode Penelitian survei dilakukan dalam hal pengumpulan data responden yakni dengan teknik kuesioner tertutup. Populasi dalam penelitian ini adalah Mahasiswa Program Studi Manajemen Semester Ganjil Tahun Akademik 2020/2021, dengan sampel sebanyak 100 orang Responden. Analisis data penelitian dengan menggunakan analisis statistik deskriptif. Hasil penelitian mengungkapkan bahwa faktor ekstrinsik yang lebih dominan memotivasi mahasiswa untuk kuliah pada Program Studi Manajemen, khususnya di STIE Jambi, yaitu sebesar 60,47\% sedangkan faktor intrinsik sebesar 39,53\%. Artinya faktor ekstrinsik lebih besar 20,94\% dibandingkan faktor intrinsik.
\end{abstract}

Kata kunci : manajemen, motivasi ekstrinsik, motivasi intrinsik, program studi.

Abstract. The main purpose of this research paper is to analyze the motivation of students in science education at Sekolah Tinggi Ilmu Ekonomi (STIE) Jambi in the odd semester with Academic Year 2020/2021. Survey research method using motivation closed questionnaire is used in this research. The population in this research are Students at the Management Study Program of academic year 2020/2021 in the odd semester, with samples of 100 Respondents. Analysis of research data using descriptive statistical analysis. These conclusion reveals that the extrinsic factor is dominate students motivation in pursuing the Management Study Program at STIE Jambi were 60,47\%, while intrinsic factors were 39,53\%. It's the meaning that the extrinsic factors were $20,94 \%$ greater than the intrinsic factors.

Keywords : management, extrinsic motivation, intrinsic motivation, study program.

\section{Pendahuluan}

Perguruan tinggi baik yang berbentuk swasta maupun negeri, menghadapi tantangan yang sama di era revolusi industri 4.0, adapun sistem dan manajemen institusi harus beradaptasi dengan kecanggihan era digital saat ini, dimana sumber daya manusia yang merupakan lulusan dari suatu institusi seyogyanya mampu bersaing ketika terjun dalam masyarakat maupun didunia bisnis dan pekerjaan. Selain daripada aspek kuantitas yang menjadi target dari suatu institusi pendidikan, aspek kualitas pun menjadi prioritas utama dalam mendukung peningkatan mutu pendidikan nasional. Salah satu institusi pendidikan di Indonesia yang terletak di Provinsi Jambi adalah Sekolah Tinggi Ilmu Ekonomi Jambi yang menjadi objek penelitian ini, dalam visi dan misi institusi tentunya mengandung dukungan terhadap pencapaian program pemerintah untuk meningkatkan kuantitas lulusan perguruan tinggi yang bermutu di Indonesia. Dalam upaya meningkatkan baik itu aspek kuantitas maupun aspek kualitas, perlu dilakukannya suatu riset yang menelusuri motivasi mahasiswa menempuh kuliah pada program studi tertentu yang salah satunya adalah program studi Manajemen. Dengan tujuan, institusi dapat merancang strategi yang tepat dalam berbagai aspek sesuai dengan keinginan calon mahasiswa sehingga menjadi daya tarik tersendiri bagi mahasiswa baru untuk masuk pada program studi ataupun institusi yang dikelola. Selain itu, melalui informasi yang diperoleh terkait motivasi mahasiswa, pihak pengelola institusi dapat merancang strategi, program, maupun kurikulum yang mampu mendorong mahasiswa untuk memberikan prestasi yang baik, dan tentu akan berdampak postif bagi perkembangan institusi dan juga mahasiswa tersebut dalam mencapai tujuannya.

Undang-Undang No. 14 tahun 2005 menjelaskan bahwa Dosen adalah pendidik profesional dan ilmuwan dengan tugas utama mentransformasikan, mengembangkan, dan menyebarluaskan ilmu pengetahuan, teknologi, dan seni melalui pendidikan, penelitian, dan pengabdian kepada masyarakat. (UU Nomor 14, 2005). Dalam hal ini, dosen sebagai tenaga pendidik perlu mendukung visi dan misi institusi dalam meningkatkan aspek kualitas mahasiswa, yakni dengan memberikan dorongan kepada mahasiswa untuk meningkatkan kompetensi dan ketrampilan diri dalam mencapai tujuan ataupun keinginan mahasiswa tersebut, yang melatar belakangi mahasiswa memilih kuliah pada jurusan atau program studi tertentu (Sari 2018). Sabry Daif-Allah dan Aljumah (2020) menyatakan bahwa motivasi adalah faktor pendorong internal yang menggerakkan seseorang untuk melakukan secara optimal hal-hal yang dapat memenuhi kebutuhannya. Menurut Pinder (Ridho 2020) bahwa motivasi merupakan energi yang bersumber dari dalam maupun luar individu yang membentuk sikap individu. Menurut Yorks, 2001 (Andjarwati, 2015) motivasi merupakan sebuah kekuatan yang menggerakkan individu untuk memenuhi kebutuhan dan keinginannya. Sedangkan 
menurut Ikawati et al., 2015 (Muhlisin 2017), motivasi adalah kondisi yang mengaktifkan seseorang untuk bertindak dalam mencapai suatu tujuan. Berdasarkan definisi-definisi yang telah dikemukakan tersebut maka dapat diketahui bahwa motivasi merupakan energi yang bersumber dari luar maupun dalam diri individu, yang mengaktifkan individu tersebut untuk bersikap dan berperilaku, dalam rangka merealisasikan suatu keputusan atas dasar kebutuhan guna mencapai tujuan.

Menurut Woodworth dan Marques (Ulfah 2015), motivasi dapat diklasifikasikan menjadi motivasi intrinsik yang berasal dari dalam diri individu serta motivasi ekstrinsik yang berasal dari eksternal individu. Motivasi ekstrinsik terkait perilaku individu yang memperoleh stimulus dari luar ataupun sarana prasarana di lingkungannya, untuk memenuhi kebutuhan dan tujuannya (Wong et al., 2013). Faktor-faktor yang mempengaruhi motivasi ekstrinsik yaitu keluarga, saudara/ anggota keluarga maupun juga teman. Kecenderungan yang terjadi pada motivasi ekstrinsik adalah sebuah pembuktian kompetensi dari mahasiswa berupa prestasi baik akademik maupun juga non akademik, sedangkan motivasi intrinsik menggerakkan mahasiswa tersebut untuk mengembangkan kemampuan yang telah dimiliki. (Handayani 2017). Sementara untuk motivasi intrinsik, Moustakas (2018 menyatakan bahwa motivasi yang dapat bersumber dari lingkungan internal maupun juga lingkungan eksternal, merupakan serangkaian faktor yang memberikan pengaruh terhadap perilaku individu untuk memenuhi kebutuhan dan mencapai tujuannya.

Sekolah Tinggi Ilmu Ekonomi Jambi merupakan perguruan tinggi swasta yang saat ini memiliki dua program studi yakni Program Studi Manajemen dan Program Studi Akuntansi, dimana institusi tersebut tentunya memiliki mahasiswa dari berbagai latar belakang, sehingga motif untuk kuliah pada salah satu program studi di STIE Jambi juga tentunya beragam. Berdasarkan informasi yang diperoleh dari mahasiswa STIE Jambi pada program studi Manajemen, bahwa motivasi awal masuk program studi ini adalah dengan beragam alasan, ada yang ingin mengembangkan karir yang tengah digeluti saat ini, ada yang memang berkeinginan menjadi seorang manajer, ada yang ingin menjadi wirausaha agar kelak dapat membuka lapangan pekerjaan, ada yang ingin meningkatkan ilmu dan ketrampilan, dan ada pula karena ingin dekat dengan keluarga ketimbang harus kuliah diluar kota.

Informasi diatas menunjukkan bahwa sangat bervariasinya motivasi yang melatarbelakangi mahasiswa untuk kuliah pada program studi tertentu. Oleh karena itu, peneliti perlu mengadakan penelitian untuk mengetahui motivasi mahasiswa baik itu secara intrinsik maupun juga ekstrinsik. Sehingga dapat diketahui kondisi yang sebenarnya terkait motivasi diri mahasiswa, untuk dapat mengatur program dan kurikulum apa yang relevan dalam rangka mengembangkan kualitas dan kuantitas mahasiswa. Dengan mengetahui motivasi mahasiswa tersebut, maka Perguruan tinggi dalam hal ini dapat membuat strategi yang tepat guna Menyusun program maupun kurikulum yang dapat menarik minat mahasiswa baru, sehingga dapat mengarahkan mahasiswa kepada tujuan dasarnya kuliah pada program studi Manajemen. Dimana baik aspek kuantitas maupun aspek kualitas menjadi perhatian khusus bagi pihak institusi dalam mendukung upaya pemerintah meningkatkan jumlah lulusan perguruan tinggi yang bermutu. Standarisasi mutu lulusan perlu menjadi perhatian dalam dunia pendidikan, selain daripada aspek kuantitas yang juga perlu ditingkatkan. Esensinya adalah bagaimana pengelolaan manajemen perguruan tinggi dilakukan secara efektif dan efisien mengarah kepada terbentuknya lulusan yang bermutu dan berkualitas (Asmawi, 2005).

Mc Shane, Olekalns, dan Travaglione, 2013 (Amir 2015) menyatakan salah satu model yang menggambarkan secara komprehensif dalam memahami perilaku individu dalam suatu organisasi yakni motivasi, ability, role perception, dan situational factors, atau disebut model MARS. Motivasi menurut pakar tersebut bertautan dengan kekuatan pada diri sesorang yang mempengaruhi arah, keinginan, dan persistensinya dalam berperilaku tertentu. Ada banyak penelitian yang menggali motivasi mahasiswa, yang menganalisis variabel itu sendiri maupun melihat hubungan ataupun pengaruh variabel motivasi dengan variabel lainnya. Berdasarkan uraian latar belakang diatas maka menarik bagi peneliti untuk menganalisa motivasi mahasiswa khususnya pada program studi Manajemen di Sekolah Tinggi Ilmu Ekonomi Jambi. Adapun urgensi dari penelitian ini adalah untuk mengetahui motivasi intrinsik maupun motivasi ekstrinsik yang menggerakkan mahasiswa untuk kuliah pada program studi Manajemen di Sekolah Tinggi Ilmu Ekonomi Jambi.

\section{Metode}

Penelitian ini merupakan penelitian survei dengan sampel penelitian adalah mahasiswa Sekolah Tinggi Ilmu Ekonomi Jambi Jenjang Strata-1, yakni Mahasiswa yang aktif dan terdaftar pada Program Studi Manajemen Semester Genab Tahun Akademik 2020/2021. Teknik analisis data penelitian menggunakan statistik deskriptif, dengan mengolah data primer dan data sekunder. Statistik deskriptif menurut Sujarweni (2015) merupakan pengolahan data dengan tujuan menggambarkan objek penelitian melalui data sampel ataupun populasi yang dapat disajikan dalam bentuk tabel, grafik, maupun diagram, biasanya hanya mengolah satu variabel saja. Data primer dalam penelitian ini adalah data menyangkut motivasi mahasiswa. Sedangkan data sekunder meliputi, data-data terkait responden serta informasi-informasi pendukung lainnya. Teknik pengumpulan data menggunakan kuesioner tertutup dengan menggunakan skala likert 1 s.d 5, dimana responden dapat memilih alternatif jawaban yang disediakan. Kuesioner disebarkan kepada responden yang diambil sampelnya, yakni dengan teknik accidental sampling atau responden yang 
Prayetno Agustinus Sitanggang dan Friska Artaria Sitanggang, Analisis Motivasi Mahasiswa dalam Menempuh Kuliah pada Program Studi Manajemen Jenjang Strata-1 Sekolah Tinggi Ilmu Ekonomi Jambi

secara kebetulan bertemu dengan peneliti. Skala likert adalah skala yang digunakan untuk mengukur motivasi individu maupun kelompok atas suatu kondisi ataupun gejala sosial yang terjadi (Eko Putro Widoyoko, 2012) .

\section{Hasil}

\section{Karakteristik Responden Berdasarkan Jenis Kelamin}

Penyebaran kuesioner yang dilakukan oleh peneliti dapat diketahui bahwa karakteristik responden berdasarkan jenis kelamin, adalah responden laki-laki yaitu 48 orang responden atau sebanyak $48 \%$ dan perempuan yaitu 52 orang responden atau $52 \%$.

\section{Gambar 1. \\ Karakteristik Responden Berdasarkan Jenis Kelamin \\ Jenis Kelamin}

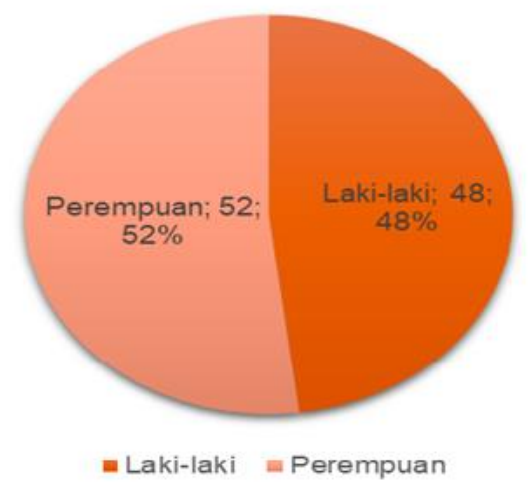

Sumber: data olahan

\section{Karakteristik Responden Berdasarkan Profesi}

\section{Gambar 2 \\ Karakteristik Responden Berdasarkan Profesi \\ Profesi Responden}

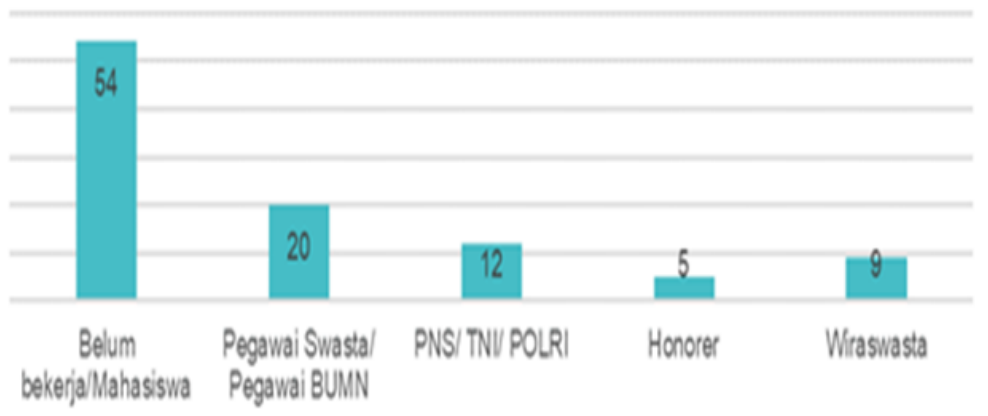

Sumber: data olahan

Berdasarkan profesi responden, diketahui bahwa 54\% responden berstatus murni mahasiswa atau belum bekerja, $20 \%$ berstatus mahasiswa sembari bekerja sebagai pegawai pada Instansi Swasta/ BUMN, 12\% berstatus mahasiswa yang juga bekerja pada Instansi Pemerintah yakni sebagai PNS/TNI/POLRI, 5\% responden merupakan pegawai honorer pada instansi pemerintah, dan sebanyak $9 \%$ berstatus mahasiswa sambil berwiraswasta.

\section{Karakteristik Responden Berdasarkan Latar Belakang Pendidikan}

Berdasarkan gambar grafik dibawah, diketahui bahwa Mahasiswa STIE Jambi lebih didominasi dengan latar belakang pendidikan asal SMA Negeri/ Swasta, daripada yang berasal dari SMK Negeri/ Swasta maupun juga Madrasah Aliyah. Adapun dari 100 responden yang diteliti, sebanyak 39 responden (39\%) asal SMK Negeri/ Swasta, sebanyak 58 responden (58\%) asal SMA Negeri/ Swasta, dan sebanyak 3 responden (3\%) asal Madrasah Aliyah. 
Gambar 3.

Karakteristik Responden Berdasarkan Latar Belakang Pendidikan

Latar Belakang Pendidikan Mahasiswa

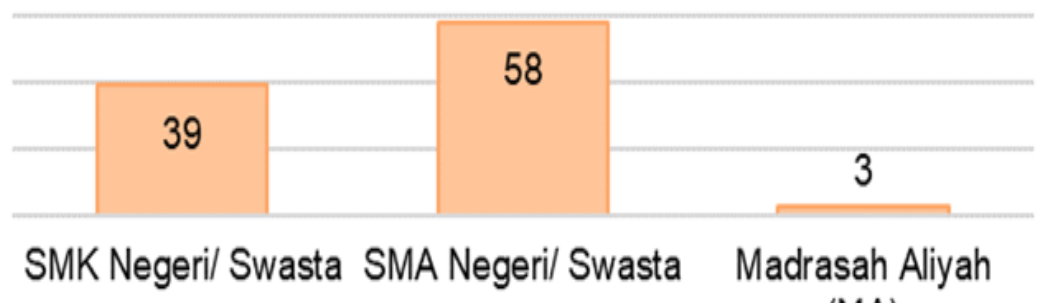

(MA)

Sumber: data olahan

Hasil pembahasan diketahui bahwa motivasi Mahasiswa dalam menempuh kuliah pada Program Studi Manajemen di Sekolah Tinggi Ilmu Ekonomi Jambi dipengaruhi oleh banyak faktor. Mahasiswa memberikan variasi jawaban yang berbeda, yakni dalam menanggapi pertanyaan dalam kuesioner yang diberikan.

Tabel 1

Hasil Tanggapan Mahasiswa berdasarkan Motivasi

\begin{tabular}{|c|c|c|c|}
\hline No. & Faktor & Indikator & Persentase \\
\hline \multirow[t]{5}{*}{1} & Faktor Ekstrinsik & - $\quad$ Dukungan orangtua & $12,95 \%$ \\
\hline & $(60,47 \%)$ & - Dukungan saudara ataupun anggota keluarga & $11,61 \%$ \\
\hline & & - Jejak kesuksesan alumni & $12,81 \%$ \\
\hline & & - $\quad$ Teman-teman sekolah asal & $10,86 \%$ \\
\hline & & - Teman-teman maupun sahabat dekat & $12,24 \%$ \\
\hline \multirow[t]{5}{*}{2} & $\begin{array}{l}\text { Faktor Intrinsik } \\
(39,53 \%)\end{array}$ & $\begin{array}{l}\text { - ingin meraih kesuksesan dalam karir dan memiliki skill manajemen, } \\
\text { seperti peran sebagai manajer atau sukses dalam meraih jenjang }\end{array}$ & \\
\hline & & karir yang lebih tinggi. & $13,16 \%$ \\
\hline & & $\begin{array}{l}\text { - } \quad \text { ingin mendapatkan pekerjaan yang bisa bekerja secara team work } \\
\text { serta mengaplikasikan skill manajemen, seperti peran sebagai }\end{array}$ & \\
\hline & & karyawan suatu organisasi atau perusahaan. & $13,21 \%$ \\
\hline & & $\begin{array}{l}\text { - ingin memimpin sebuah bisnis dengan skill manajemen yang } \\
\text { dimiliki, seperti peran sebagai entrepreneur. }\end{array}$ & $13,16 \%$ \\
\hline
\end{tabular}

Sumber: data olahan

Berdasarkan Tabel 1 diatas diperoleh informasi bahwa faktor intrinsik yang paling tinggi yaitu keinginan mendapatkan pekerjaan yang bisa bekerja secara team work serta mengaplikasikan skill manajemen, kecenderungan yang ditunjukkan adalah peran sebagai seorang karyawan yang dituntut untuk bekerja secara team work dengan persentase 13,21\%. Hal tersebut sejalan dengan hasil penelitian Indarti dan Wulandaru (2003), yang menyatakan bahwa tingkat rata-rata kebutuhan afiliasi untuk karyawan lebih tinggi jika dibandingkan dengan entrepreneur, karena karyawan lebih cenderung melakukan pekerjaan dengan membangun kerjasama antar bagian dalam suatu organisasi untuk menyelesaikan pekerjaannya. Besarnya persentase kebutuhan afiliasi yang direfleksikan dalam peran sebagai karyawan tersebut, memberikan pengertian bahwa motivasi mahasiswa masih berorientasi pada paradigma pencari kerja (job seekers), yang artinya setelah menyelesaikan pendidikan maka mahasiswa berkeinginan menjadi seorang karyawan pada sebuah organisasi ataupun perusahaan. Dari Faktor ekstrinsik berdasarkan Tabel diatas diketahui bahwa yang paling besar persentase pengaruhnya adalah dukungan dari orangtua. Hal tersebut memberikan gambaran bahwa mahasiswa dalam memilih program studi Manajemen mendapatkan dorongan ataupun motivasi dari orangtua dan juga keluarga terdekatnya, Hasil penelitian tersebut relevan dengan teori yang dinyatakan Anwar P.M, 1988 (Sunyoto 2015) bahwa keluarga sangat memberi pengaruh dalam pengambilan keputusan konsumen yang dalam hal ini adalah mahasiswa. Referensi kelompok seperti Alumni yang telah sukses juga bisa memberi dorongan bagi mahasiswa, karena keinginan meraih kesuksesan yang sama seperti yang telah diraih oleh para alumni. Nitisusastro (2012), bahwa dalam referensi kelompok adanya publik figur ataupun sekelompok orang dalam masyarakat yang memiliki sikap dan ciri tertentu, menjadi acuan dalaam berperilaku yang dalam hal ini adalah perilaku mahasiswa. 
Prayetno Agustinus Sitanggang dan Friska Artaria Sitanggang, Analisis Motivasi Mahasiswa dalam Menempuh Kuliah pada Program Studi Manajemen Jenjang Strata-1 Sekolah Tinggi Ilmu Ekonomi Jambi

\section{Gambar 4. \\ Faktor Motivasi Mahasiswa Dalam Menempuh Kuliah Pada Program Studi Manajemen Jenjang Strata-1 Sekolah Tinggi Ilmu Ekonomi Jambi}

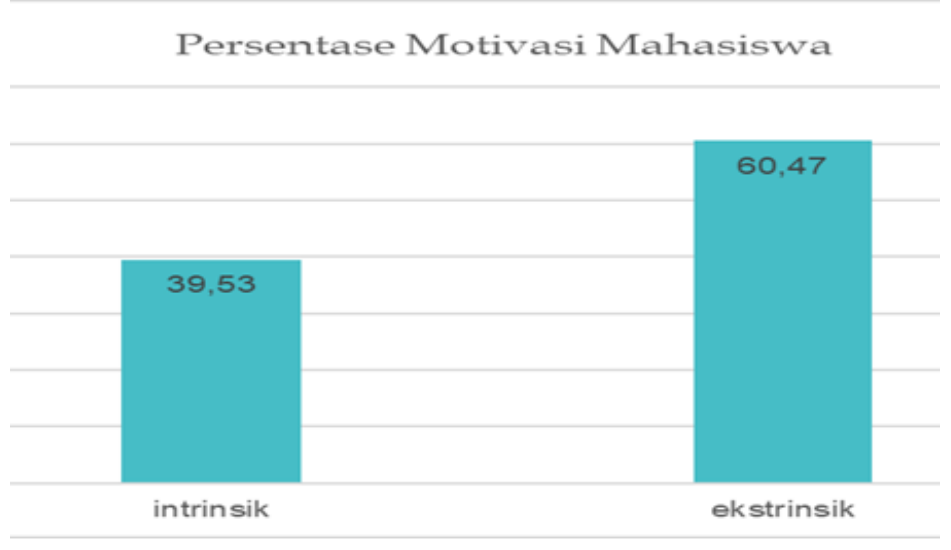

Sumber: data olahan

Gambar 4 diatas menunjukkan perbedaan persentase antara faktor intrinsik dan ekstrinsik yang mempengaruhi mahasiswa dalam menempuh Program Sarjana Ekonomi pada Jurusan Manajemen, dimana motivasi intrinsik sebesar $39,53 \%$, sedangkan motivasi ekstrinsik adalah sebesar 60,47\% yang digerakkan oleh orangtua, saudara/ anggota keluarga, alumni, teman-teman asal sekolah, maupun juga teman-teman dan sahabat. Faktor ekstrinsik lebih besar 20,94\% dibandingkan faktor intrinsik, sementara motivasi intrinsik yang merupakan dorongan dari dalam diri mahasiswa merupakan faktor yang perlu dimaksimalkan untuk mencapai tujuan. Hasil penelitian ini berbeda dengan hasil penelitian Ulfah (2015) dimana yang lebih mendominasi motivasi mahasiswa adalah faktor intrinsik, dinyatakan bahwa faktor intrinsik cenderung lebih permanen sifatnya untuk mendorong seorang mahasiswa dalam mencapai tujuannya, ketimbang faktor ekstrinsik yang berasal dari lingkungan ekternal. Handayani (2017) dalam penelitiannya juga menyatakan hasil yang sama dengan Ulfah (2015) bahwa motivasi mahasiswa didominasi oleh motivasi intrinsik dibandingkan motivasi ekstrinsik. Santrock, 1999 (Dariyo 2004) menyatakan bahwa motivasi yang berasal dari faktor eksternal cenderung bersifat temporari, karena jika individu tidak memperoleh stimulus dari lingkungan ekternalnya maka individu tersebut akan kehilangan semangat dalam melakukan aktivitas. Sebagaimana pernyataan Aldosari (2014) (Sabry Daif-Allah dan Aljumah 2020), menyatakan bahwa penghargaan dan pengalaman yang diperoleh dari lingkungan eksternal, bisa mengontrol individu dalam berperilaku, akan tetapi stimulus yang diterima harus ditanggapi secara positif, sebab jika suatu saat individu tersebut tidak memperoleh kembali dukungan ekternal maka individu akan tetap beraktivitas dengan semangat dan motivasi yang berasal dari dalam dirinya. Dengan kata lain, setiap mahasiswa harus dapat meningkatkan motivasi dari dalam diri mahasiswa tersebut, untuk berpartisipasi secara aktif dalam mencapai tujuan.

Penelitian ini juga sama-sama menelaah motivasi intrinsik dan ekstrinsik, sebagaimana penelitian yang dilakukan oleh Semiz dan Salman (2017), berdasarkan hasil yang diperoleh bahwa teman dan keluarga sebagai faktor ekstrinsik tidak memberikan pengaruh yang dominan terhadap siswa, peningkatan keterampilan bahasa dan karir masa depan dinyatakan paling berpengaruh terhadap siswa. Atau dengan kata lain, faktor intrinsik yang lebih dominan ketimbang faktor ekstrinsik. Namun kondisi yang berbeda terjadi pada objek penelitian ini, dimana motivasi ekstrinsik memiliki persentase yang lebih besar dibandingkan dengan motivasi intrinsik, sehingga pihak institusi perlu meningkatkan motivasi intrinsik pada masing-masing mahasiswa, dengan tetap menjaga komunikasi yang baik kepada orangtua mahasiswa yang memiliki persentase lebih besar yakni $12,95 \%$ dibandingkan dengan dukungan indikator lainnya, jejak alumni menempati urutan kedua dengan persentase 12,81\%, diikuti dengan dukungan dari teman-teman/ sahabat $(12,24 \%)$, saudara atau anggota keluarga $(11,61 \%)$, dan teman-teman asal sekolah $(10,86 \%)$. Merujuk dari hasil yang diperoleh bahwa jejak kesuksesan alumni juga cukup mempengaruhi motivasi mahasiswa untuk kuliah pada program studi Manajemen, tentunya hal tersebut dapat menjadi masukan bagi pihak intitusi untuk mengembangkan program tracer study atau program lainnya yang relevan dalam meningkatkan hubungan para alumni dengan perguruan tinggi asal alumni tersebut.

Hasil penelitian ini sejalan dengan hasil penelitian Aransi (2019), yang menyatakan bahwa faktor sosial merupakan motivasi ekstrinsik yang didalamnya sama-sama mendapatkan dukungan peran ganda keluarga, dinyatakan berpengaruh secara siginifikan terhadap partisipasi mahasiswa dalam mengikuti program studi di Osun State, Nigeria. sedangkan untuk faktor psikologis dan faktor ekonomi dinyatakan tidak ada perbedaan yang signifikan. Hasil penelitian ini juga sejalan dengan hasil penelitian Muhlisin (2017), dimana faktor ekstrinsik yang mempengaruhi mahasiswa lebih besar jika dibandingkan dengan faktor intrinsik, sementara motivasi intrinsik seyogyanya harus lebih 
besar daripada faktor ekstrinsik agar mahasiswa dapat bertingkah laku mengarah kepada tujuan secara optimal. Razzaq (2016) (Muhlisin 2017) bahwa faktor ekstrinsik bersifat sementara waktu, berbeda dengan faktor intrinsik yang lahir dari dalam diri mahasiswa tersebut. Motivasi intrinsik mengacu pada motivasi seseorang untuk terlibat secara langsung dalam suatu pekerjaan tanpa adanya rasa keterpaksaan sehingga menyenangkan untuk dilakukan.(Sabry Daif-Allah dan Aljumah 2020). Sebagaimana yang dinyatakan dalam teori Mc.Clelland bahwa ada tiga motivasi individu, yakni motivasi yang didasarkan atas kebutuhan pencapaian (sukses), kebutuhan kekuasaan, dan kebutuhan hubungan (afiliasi). Fauzie, Yulianto, dan Sunarti (2016) menyatakan bahwa sebagian individu mempunyai dorongan yang kuat sekali untuk mencapai suatu keberhasilan sehingga berupaya semaksimal mungkin untuk meraih apa yang diinginkan, dimana dari riset Mc.Clelland terkait kebutuhan pencapaian menyatakan bahwa motivasi yang lebih tinggi terjadi dalam diri peraih prestasi tinggi dibandingkan seseorang yang pencapaiannya biasa-biasa saja. Selanjutnya untuk faktor pendorong yang kedua adalah kebutuhan akan kekuasaan yakni hasrat untuk mempunyai pengaruh serta dapat mengendalikan orang lain, seseorang dengan motivasi yang tinggi atas dasar kebutuhan ini cenderung lebih menyukai kondisi yang kompetitif sebagaimana peran yang ditunjukkan oleh seorang entrepreneur yang tentunya melakukan inovasi dan kreatifitas tanpa batas dalam produk dan jasa yang ditawarkan untuk bersaing dengan para kompetitor bisnisnya. Sementara faktor ketiga, adalah kebutuhan afiliasi atau hubungan, dimana individu dengan motif afiliasi tinggi akan berjuang keras untuk persahabatan, lebih menyukai situasi yang kooperatif daripada situasi kompetitif. Individu yang memiliki kebutuhan afiliasi akan terlibat aktif dalam aktivitas yang melibatkan banyak orang, serta memilih produk dan jasa yang disenangi oleh teman dan kerabat dekatnya.(Balqiah dan Setyowardhani 2017).

Berdasarkan teori yang dinyatakan oleh Mc.Clelland tersebut, maka dalam penelitian ini motif mahasiswa kuliah pada program studi Manajemen salah satunya dilatarbelakangi oleh dorongan dari dalam diri mahasiswa tersebut (intrinsik), yakni untuk memenuhi kebutuhannya terhadap pencapaian dimasa depan $(13,16 \%)$, demikian pula kebutuhan akan kekuasaan (13,21\%), dan kebutuhan afiliasi (13,16\%). Kebutuhan akan afiliasi mendominasi motivasi ekstrinsik mahasiswa yakni sebesar $13,21 \%$, kebutuhan ini direfleksikan dengan keinginan mendapatkan suatu pekerjaan ketika mahasiswa menyelesaikan studinya. Adapun pekerjaan yang dimaksudkan adalah jenis pekerjaan yang memberikan peluang yang besar bagi individu untuk berinteraksi atau bekerja secara team work guna menyelesaikan tugas-tugasnya, sebagaimana peran sebagai seorang karyawan dalam suatu perusahaan yang menuntut adanya kerja yang terintegrasi antar bagian dalam organisasi. Selanjutnya, kebutuhan akan kesuksesan serta kebutuhan kekuasaan memiliki persentase yang sama, yakni 13,16\%. Kebutuhan akan kekuasaan direfleksikan dengan keinginan memimpin sebuah bisnis dengan skill manajemen yang dimiliki, sebagaimana peran yang ditunjukkan oleh seorang entrepreneur. Sedangkan kebutuhan pencapaian, direfleksikan dengan pekerjaan sebagai seorang manajer ataupun pekerjaan lainnya yang memiliki jenjang karir.

Namun dalam penelitian ini diperoleh hasil persentase yang lebih besar untuk kebutuhan afiliasi yang merefleksikan pekerjaan sebagai seorang karyawan bukan sebagai entrepreneur yang diharapkan oleh institusi maupun juga pemerintah, sehingga dalam hal ini perlunya peran institusi untuk memotivasi mahasiswanya menjadi entrepenur yakni dengan mengembangkan karakter kewirausahaan dalam praktek serta pendidikan yang dijalankan, memberikan pengalaman berwirausaha bagi para mahasiswa, ataupun mengikut sertakan mahasiswa dalam kegiatan seminar atau pelatihan kewirausahaan. Hal tersebut dilakukan guna mendukung program pemerintah dalam menghasilkan lulusan dari berbagai bidang ilmu termasuk program studi Manajemen, yang nantinya mampu menciptakan lapangan pekerjaan baru dan bukan pencari kerja (job seekers), untuk menjadikan Indonesia menjadi negara maju pada tahun 2045 nanti, dan program tersebut didukung penuh oleh Kementerian Riset, Teknologi, dan PendidikanTinggi melalui Direktorat Jenderal Pembelajaran dan Kemahasiswaan.(Hasni 2018).

Salah satu faktor terpenting yang menggerakkan partisipasi individu dalam memanfaatkan waktu dan kesempatannya, berdasarkan hasil penelitian Selman Özdemir (2020) adalah motivasi intrinsik. Banyak peneliti yang memberikan penekanan terhadap pentingnya membangkitkan motivasi intrinsik untuk menggerakan individu tersebut kearah pencapaian tujuan, sehingga riset terkait sumber motivasi intrinsik sangat penting untuk diketahui. Pihak institusi perlu memahami apa yang memotivasi partisipasi mahasiswa di kampus, dengan menjalankan program yang mampu memaksimalkan partisipasi yang ditunjukkan oleh mahasiswa. Penelitian. Selman Özdemir (2020) melihat hubungan antara motivasi intrinsik dan motivasi ekstrinsik yang merupakan satu kekuatan, yang mampu menggerakkan partisipasi aktif mahasiswa dalam menjalankan kegiatan ataupun program yang dirancang oleh pihak institusi.

\section{Simpulan}

Berdasarkan analisis data dan pembahasan yang telah diuraikan, maka dapat disimpulkan bahwa motivasi mahasiswa masuk program studi Manajemen pada Sekolah Tinggi Ilmu Ekonomi Jambi dipengaruhi oleh banyak faktor yang dapat diklasifikasikan kedalam motivasi intrinsik dan motivasi ekstrinsik. Motivasi intrinsik yang mempengaruhi mahasiwa STIE Jambi masuk pada program studi Manajemen diantaranya; ingin meraih kesuksesan 
dalam karir dan memiliki skill manajemen, ingin mendapatkan karir yang bisa bekerja secara team work serta mengaplikasikan skill manajemen, serta ingin menjadi entrepreneur yang dapat memimpin sebuah bisnis dengan skill manajemen yang dimiliki. Sedangkan motivasi ekstrinsiknya antara lain; karena mendapatkan dukungan dari orang tua, saudara atau anggota keluarga, karena ingin mengikuti jejak alumni yang telah sukses, mengikuti teman asal sekolah, serta mengikuti saran dari teman maupun sahabat. Motivasi intrinsik terbesar mahasiswa STIE Jambi masuk program studi Manajemen yakni didasari oleh kebutuhan afiliasi atau pertalian yakni keinginan untuk mendapatkan pekerjaan yang bisa bekerja secara team work serta mengaplikasikan skill manajemen (job seekers) sebesar 13,21\%, untuk motivasi yang didasari kebutuhan akan kesuksesan yakni sukses mencapai jenjang karir yang diinginkan memiliki persentase sebanyak 13,16\%, keinginan tersebut cenderung dilatarbelakangi oleh kondisi mahasiswa yang sebagian memang adalah pekerja, baik yang bekerja sebagai tenaga honorer (5\%), pegawai swasta/ BUMN (20\%), pegawai negeri/ TNI/ POLRI (12\%), dan ada pula yang bekerja sebagai wiraswasta (9\%), sementara sisanya $54 \%$ adalah murni mahasiswa (belum bekerja). Selanjutnya persentase yang sama yakni 13,16\% merupakan keinginan untuk memimpin sebuah bisnis sebagai seorang entrepreneur. Sedangkan untuk motivasi ekstrinsik terbesar mahasiswa STIE Jambi masuk program studi Manajemen yakni karena mendapatkan dukungan orang tua. Sehingga persentase dari motivasi intrinstik dan motivasi ekstrinsik mahasiswa STIE Jambi untuk kuliah pada program studi Manajemen, masing-masing sebesar 39,53\% dan 60,47\%.

Diketahuinya faktor-faktor yang mendorong mahasiswa untuk kuliah pada program studi Manajemen, maka pihak institusi dalam hal ini dapat mengembangkan strategi, program maupun kurikulum yang tepat dan sesuai dengan visi dan misi institusi, yang dapat membantu mahasiswa mencapai apa yang diinginkan untuk masa depannya, sehingga mahasiswa akan menjalankan perkuliahan dengan dorongan penuh yang lahir dari dalam diri mahasiswa tersebut tanpa adanya unsur keterpaksaan, karena dilapangan juga kemungkinan dapat ditemui adanya mahasiswa yang kuliah pada program studi tertentu untuk memenuhi keinginan orang tuanya semata, tentunya hal tersebut dapat menimbulkan masalah besar bagi mahasiswa bersangkutan. Motivasi menjadi entrepreneur yang diharapkan lebih dominan, ternyata dari hasil penelitian memiliki persentase yang lebih kecil jika dibandingkan dengan keinginan mahasiswa mendapatkan pekerjaan di masa depan sebagai seorang karyawan/ pegawai suatu organisasi atau perusahaan (job seekers), untuk itu pihak institusi perlu membentuk ataupun meningkatkan jiwa dan karakter kewirausahaan selama mengikuti perkuliahaan, yakni dengan teori maupun praktek kewirausahaan yang dapat melahirkan entrepreneur baru guna mendukung program pemerintah dalam meningkatkan perekonomian nasional bukan melahirkan karakter pencari kerja, dikarenakan terbatasnya jumlah lapangan pekerjaan yang dapat menampung para lulusan dari sekolah ataupun perguruan tinggi. Selain itu, melalui riset terkait motivasi mahasiswa, institusi juga dapat meningkatkan aspek kuantitas mahasiswanya, karena telah diketahuinya apa yang menjadi keinginan calon mahasiswa, sehingga institusi dapat menjalankan fungsi dan peranannya dalam menghantar mahasiswa mencapai tujuan dan cita-citanya.

\section{Daftar Pustaka}

Amir, M Taufiq. 2015. Merancang Kuesioner Konsep dan Panduan Untuk Penelitian. Jakarta: Prenadamedia Group. Andjarwati, Tri. 2015. Motivasi dari Sudut Pandang Teori Hirarki Kebutuhan Maslow, Teori Dua Faktor Herzberg, Tero X Y Mc Gregor, dan Teori Motivasi Prestasi Mc Clelland. Jurnal Ilmu Ekonomi \& Manajemen.

Aransi, Waliyi Olayemi. 2019. Psychosocial and economic variables as correlates of adults' participation into sandwich educational programs in Osun State, Nigeria. Journal of Education and e-Learning Research.

Asmawi, M. Rosul. 2005. Strategi Meningkatkan Lulusan Bermutu di Perguruan Tinggi. Makara Human Behavior Studies in Asia.

Balqiah, Tengku Ezni, dan Hapsari Setyowardhani. 2017. Perilaku Konsumen Perilaku Konsumen. Kesatu. Banten: Universitas Terbuka.

Dariyo, Agoes. 2004. Pengetahuan Tentang Penelitian Dan Motivasi Belajar Pada Mahasiswa. Jurnal Psikologi 2(1): 44.

Eko Putro Widoyoko, S. 2012. Teknik Penyusunan Instrumen Penelitian. Yogyakarta: Pustaka Belajar.

Fauzie, D., E. Yulianto, dan S. Sunarti. 2016. Pengaruh Faktor Psikologis Konsumen Terhadap Keputusan Pembelian (Survei Pada Konsumen KFC Cabang Mall Olympic Garden Malang). Jurnal Administrasi Bisnis S1 Universitas Brawijaya.

Handayani, Rifati Dina. 2017. Analysis of Intrinsic And Extrinsic Motivation of Physich-Teacher Student Candidates. Jurnal Kependidikan: Penelitian Inovasi Pembelajaran.

Hasni. 2018. Urgensi Pendidikan Kewirausahaan Dalam Menghasilkan Wirausahawan Muda Dari Perguruan Tinggi. Ekspose 53(9): 1689-99.

Indarti, Nurul, dan Diah Retno Wulandaru. 2003. Profil Dan Motivasi Entrepreneur Wanita. Jurnal i-lib UGM.

Moustakas, Loukas. 2018. Motivation and Obstacles to Adult Participation in Lifelong Learning Programs: The Effect of Gender and Age. Open Journal for Educational Research 2(1): 45-56. 
Prayetno Agustinus Sitanggang dan Friska Artaria Sitanggang, Analisis Motivasi Mahasiswa dalam Menempuh Kuliah pada Program Studi Manajemen Jenjang Strata-1 Sekolah Tinggi Ilmu Ekonomi Jambi

Muhlisin, Ahmad. 2017. Analisis Motivasi Mahasiswa Dalam Menempuh Program Sarjana Pendidikan IPA Universitas TIDAR. Indonesian Journal of Science and Education.

Nitisusastro, Mulyadi. 2012. Perilaku Konsumen Dalam Pespektif Kewirausahaan. Alfabeta.Bandung.: 2012.

Özdemir, Ali, dan Selman. 2020. Exploring Intrinsic Leisure Motivations Of University Students. European Journal of Education Studies 7(1): 52-65. www.oapub.org/edu.

Ridho, Muhammad. 2020. Teori Motivasi Mcclelland dan Implikasinya dalam Pembelajaran PAI. Jurnal Studi Keislaman dan Ilmu Pendidikan 8(1): 1-16.

Sabry Daif-Allah, Ayman, dan Fahad Hamad Aljumah. 2020. Differences in Motivation to Learning English among Saudi University Students. English Language Teaching.

Sari, Kurnia. 2018. Gambaran Motivasi Mahasiswa Bimbingan dan Konseling Universitas PGRI Palembang Dalam Mengikuti Perkuliahan. Prosiding Seminar Nasional 21 Universitas PGRI Palembang 53(9): 1689-99.

Semiz, Öznur, dan Özlem Salman. 2017. The Factors Determining the Motivation to Participate in Erasmus Program for Turkish EFL Students. International Journal of Curriculum and Instruction.

Sujarweni, Wiratna. 2015. SPSS Untuk Penelitian. Yogyakarta.: Pustaka Baru Press.

Sunyoto, Danang. 2015. Perilaku Konsumen dan Pemasaran. Center of Academic Publishing Service.Yogyakarta.

Ulfah, Amaliyah. 2015. Motivasi Mahasiswa Memilih Program Studi Pg Paud, Jurnal Dinamika Pendidikan Dasar 7(2): 182-96.

Undang Undang Nomor 14 Tahun 2005, RI. 2005. Undang-undang Guru dan Dosen. Produk Hukum. 